Vol. 52, z. (1-2) - 1999

$121-126$

\title{
Improved performance of muskmelon (Cucumis melo) seeds with osmoconditioning
}

\section{G. SINGH AND S.S. GILL AND KAMALJIT KAUR SANDHU}

\author{
Department of Seed Science \& Technology, Punjab Agricultural \\ University, Ludhiana-141 004 India
}

(Received: August 2, 1999)

\begin{abstract}
Su m mary
Seeds of muskmelon (Cucumis melo) cultivars viz $\mathrm{Pb}$. Hybrid and $\mathrm{Pb}$. Sunehri were osmoconditioned with Polyethylene glycol (PEG) and $\mathrm{KNO}_{3}$ solutions to enhance their performance at low temperature. Osmoconditioning both with PEG 6000 and $\mathrm{KNO}_{3}$ increased per cent germination, speed of germination, vigour in terms of dry weight and length of the seedlings and root/shoot ratios. $\mathrm{KNO}_{3}$ priming recorded more pronounced effects in all the above mentioned parameters. Other vigour parameters such as electrical conductance of seed leachates was decreased with osmoconditioning while dehydrogenase activity was enhanced. Osmoconditioning resulted in increased activity of amylases.
\end{abstract}

Key words: Muskmelon, seeds, osmoconditioning

\section{INTRODUCTION}

Early and uniform establishment of vigorous seedlings is a prerequisite for optimal field stands needed for obtaining high yields. The seeds sown out of their normal season encounter quite often various stresses in the field. In north Indian plains to raise a profitable crop of cucurbits especially muskmelon the first seeding must be done during the cold month of February when the soil temperature rarely exceeds $20^{\circ} \mathrm{C}$ while the required temperature for field emergence for these crops is above $30^{\circ} \mathrm{C}$. Seeds take more time to emerge and become susceptible to damage by various seed rot organisms. Seedlings show slow growth, thus leading to uneven and poor crop stands. Many attempts have been made to improve the performance of seeds of different crops under such suboptimal conditions with pre-sowing seed treatments including osmoconditioning. Osmoconditioning brings about many beneficial effects in the seeds ( $\mathrm{Kh}$ a n et al., 1976) such as acceleration of germination for many types of seeds at low temperature improved establishment and seedling growth (He y d e c k e r, 1977). 
Therefore, the present work was undertaken to improve the performance of muskmelon seed during germination and early seedling growth with osmoconditioning.

\section{MATERIALS AND METHODS}

Seeds of muskmelon (Cucumis melo) varieties viz. $\mathrm{Pb}$. Hybrid and $\mathrm{Pb}$.Sunehri were surface sterilized and soaked in optimum conc. of PEG (-8 bars) and $\mathrm{KNO} 3(0.35 \mathrm{M})$ solutions containing $0.2 \%$ thiram as fungicide at $150 \mathrm{C}$ for 3,5 and 7 days. The soak solutions were continuously aerated with air bubblers in PEG solutions. The treated seeds were thoroughly washed first with tap water followed by distilled water. The seeds were dried at room temperature. The seeds were germinated at $20^{\circ} \mathrm{C}$ in a B.O.D. incubator using paper towels. Untreated seeds served as control. Percent germination and seedling growth in terms of root and shoot length and their dry weight were recorded on the final count $\left(10\right.$ days at $\left.20^{\circ} \mathrm{C}\right)$. Speed of germination (SG) was calculated after Maguire (1962): $\mathrm{SG}=(\mathrm{n} / \mathrm{t})$ where $\mathrm{n}=$ number of seeds newly germinated at time ' $\mathrm{t}$ ' (days).

Fifty seeds in duplicate were dipped in $50 \mathrm{ml}$ of water for $24 \mathrm{~h}$ at $25 \pm 10 \mathrm{C}$. The seeds were removed and electrical conductance of seed leachates was recorded on electrical conductance meter (NDC 733) as mMHOS/cm.

Amylases were extracted in $0.2 \mathrm{M}$ sodium acetate buffer $(\mathrm{pH} 5.0)$ containing 0.2 mM EDTA. Amylase activity was calculated in terms of starch hydrolysed $\min ^{-1} \mathrm{~g}^{-1}$ tissue(Louis and Gifford, 1962).

DNA was extracted with 5\% perchloric acid after Smillie and Krotov (1962) and estimated after B urton (1955). Dehydrogenases were estimated with $0.08 \% 2,3,5$ triphenyl tetrazolium chloride (TTC) in terms of $\Delta \mathrm{OD} / \mathrm{g}$ tissue.

\section{RESULTS AND DISCUSSION}

Various concentrations of PEG and $\mathrm{KNO}_{3}$ were screened and - 8 bars of PEG and $0.35 \mathrm{M} \mathrm{KNO}_{3}$ were found to be optimum concentrations as there was no germination in the solution themselves. Many attempts have been made to improve the performance of seeds of various crops under sub- and supra-optimal conditions with pre-sowing seed treatments including osmoconditioning.

Osmoconditioning brings about many beneficial effects in the seeds (Khan et al., 1976). In the present set of experiments osmoconditioning with both PEG 6000 and $\mathrm{KNO}_{3}$ recorded beneficial effects in muskmelon seeds of the two cultivars viz. $\mathrm{Pb}$ Sunehri and $\mathrm{Pb}$. Hybrid for 3,5 and 7 days at $20^{\circ} \mathrm{C}$ (Table 1). Percent germination, speed of germination, seedling dry weight and length were all positively affected with osmoconditioning with both these chemicals for various durations. Our findings partly confirm the earlier findings where accelerated germination at low temperature was shown in cucurbits e.g. muskmelon (N e r s o n and G o vers 1986), watermelon ( $\mathrm{S}$ a c h s , 1977) with $\mathrm{KNO}_{3}$ osmoconditioning. A significant improvement in emergence was shown with seed priming with $\mathrm{KNO}_{3}$ and $\mathrm{KNO}_{3}+\mathrm{K}_{2} \mathrm{HPO}_{4}$ in summer squash (M a u r o m i c a le et al.1994). Further seedlings were shown to emerge more uniformly with $\mathrm{KNO}_{3}$ and PEG osmoconditioning at ordinary temperature ( $\mathrm{B} \mathrm{r}$ a d for d et al, 1988). Lanteri et al. (1998) reported faster germination in pepper seeds on priming with PEG 6000. Among PEG and $\mathrm{KNO}_{3}$, the later showed more pronounced effects on 
seed performance in terms of percent germination and its speed, dry weight and length of both root and shoot (Table 1). In a similar study in tomato seeds priming with $\mathrm{KNO}_{3}$ $+\mathrm{K}_{2} \mathrm{HPO}_{4}$ showed higher germination than that with PEG at low temperature (Mauromicale and Cavalla ro, 1997). It is interesting to note that osmoconditioning of muskmelon seeds of the two varieties recorded higher root/shoot ratios as compared with that of the control. This shows root growth occurred to a higher extent compared to that of the shoots. Such a change is of significance where the seedlings have to be grown in stressed conditions as vigorous root growth always favours adaptation to adverse environmental conditions.

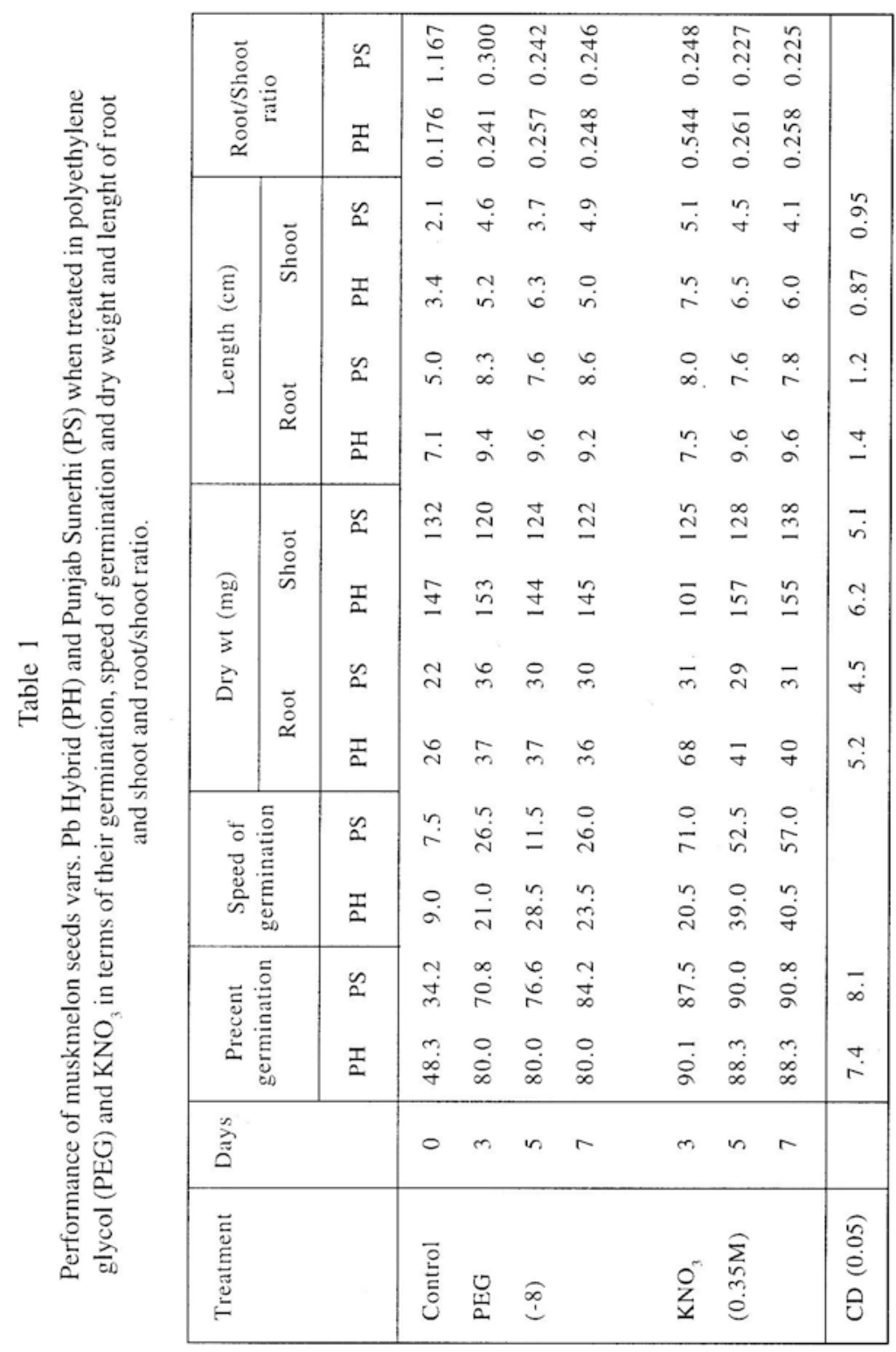


Table 2

Electrical conductance and dehydrogenase activity in osmoconditioned seeds with ( 8 bars) and $\mathrm{KNO}_{3}(0.35 \mathrm{M})$ for various days.

\begin{tabular}{|c|c|c|c|c|c|}
\hline \multirow[t]{2}{*}{ Treatment } & \multirow[t]{2}{*}{ Days } & \multicolumn{2}{|c|}{$\begin{array}{l}\text { Electrical conductance } \\
(\mathrm{mMOHS} / \mathrm{cm})\end{array}$} & \multicolumn{2}{|c|}{$\begin{array}{l}\text { Dehydrogenase } \\
\text { activity }(\Delta \mathrm{OD})\end{array}$} \\
\hline & & $\mathrm{PH}$ & PS & $\mathrm{PH}$ & PS \\
\hline Control & 0 & 0.150 & 0.055 & 0.611 & 0.588 \\
\hline PEG & 3 & 0.040 & 0.020 & 0.662 & 0.681 \\
\hline \multirow[t]{3}{*}{ ( -8 bars) } & 5 & 0.040 & 0.020 & 0.699 & 0.630 \\
\hline & 7 & 0.035 & 0.025 & 0.775 & 0.596 \\
\hline & 0 & 0.615 & 0.375 & 0.611 & 0.588 \\
\hline $\mathrm{KNO}_{3}$ & 3 & 0.565 & 0.320 & 0.651 & 0.724 \\
\hline \multirow[t]{2}{*}{$(35 \mathrm{M})$} & 5 & 0.505 & 0.320 & 0.656 & 0.707 \\
\hline & 7 & 0.570 & 0.335 & 0.589 & 0.606 \\
\hline $\mathrm{CD}(0.05)$ & & 0.031 & 0.030 & 0.025 & 0.019 \\
\hline
\end{tabular}

Table 3

Amylase activity ( $\mu \mathrm{g}$ starch hydrolysed $\mathrm{min}^{-1} \mathrm{~g}^{-1}$ fresh wt) and DNA $\mu \mathrm{g} \mathrm{g}^{-1}$ d.wt content in 3 days osmoconditioned seed with PEG and $\mathrm{KNO}_{3}$

\begin{tabular}{|c|c|c|c|c|}
\hline & \multicolumn{2}{|c|}{$\begin{array}{c}\text { *Amylase activity } \pm \text { SE } \\
\left(\mu \mathrm{g} \text { starch hydrolysed } \min ^{-1} \mathrm{~g}^{-1} \mathrm{fw}\right)\end{array}$} & \multicolumn{2}{|c|}{$\begin{array}{c}\mathrm{DNA} \pm \mathrm{SE} \\
\left(\mu \mathrm{g} \mathrm{g}^{-1} \mathrm{~d} . w \mathrm{t}\right)\end{array}$} \\
\hline & $\mathrm{PH}$ & PS & PH & PS \\
\hline Control & $\begin{array}{c}292 \pm .13 \\
(11.9)\end{array}$ & $\begin{array}{c}266 \pm 11 \\
(10.2)\end{array}$ & $1.637 \pm .021$ & $2.222 \pm .016$ \\
\hline PEG (-8 bars) & $\begin{array}{l}323 \pm 10 \\
(14.7)\end{array}$ & $\begin{array}{l}267 \pm 9 \\
(19.2)\end{array}$ & $1.765 \pm .019$ & $1.835 \pm .013$ \\
\hline $\begin{array}{l}\mathrm{KNO}_{3} \\
(0.35 \mathrm{M})\end{array}$ & $\begin{array}{c}342 \pm 13 \\
(14.6)\end{array}$ & $\begin{array}{c}316 \pm 13 \\
(10.6)\end{array}$ & $1.807 \pm .022$ & $2.985 \pm .017$ \\
\hline
\end{tabular}

*Values in parentheses $=$ Amylase activity per

One of the early events which seems to be associated with seed quality is the solute efflux from seeds which is an indirect measure of membrane integrity of the cells insides the seeds. Electrical conductance of seed leachates was reduced with $\mathrm{KNO}_{3}$ and PEG osmoconditioning which indicates improvement in the seed vigour 
(Table 2). Low leakage of solutes was associated with high seed vigour while low vigour seeds recorded high conductivity (M thew s and Whit e bre ad, 1968).

Activity of certain preformed enzymes such as dehydrogenases are positively correlated with seed vigour. Its higher activity suggests higher vigour of seeds and vice versa. Dehydrogenase activity was increased in osmoconditioned seeds of muskmelon varieties thus indicating again the positive affect of osmoconditioning in terms of increased vigour (Table 2).

Amylase activity increased in seeds of the two cultivars on osmoconditioning with PEG and $\mathrm{KNO}_{3}$ (Table 3). This shows that the seeds were actively metabolizing which is a sign of vigourous seeds.

DNA content was increased with osmoconditioning with $\mathrm{KNO}_{3}$ and PEG as compared to control in $\mathrm{Pb}$. Hybrid while such an increase was noticed with $\mathrm{KNO}_{3}$ in Punjab Sunehri and with PEG a reduction was shown (Table 3). Sen and O s b or n e (1974) reported higher rate of DNA, RNA and protein synthesis in dried embryos of rye after hydrate and dehydrate treatments. De ll ' A quill a and Tar a n to (1986) showed a fast resumption of cell division and DNA synthesis in primed seeds on re-watering. Our data suggests that osmoconditioning brings about cell division as indicated by increased $\mathrm{DNA}$ content in $\mathrm{Pb}$. hybrid with $\mathrm{PEG}$ and $\mathrm{KNO}_{3}$ priming and $\mathrm{Pb}$. Sunehri with $\mathrm{KNO}_{3}$ priming while in $\mathrm{Pb}$. Sunehri positive effects of osmoconditioning with PEG were brought about by cell expansion only as indicated by reduction or no change in the DNA content. L a n t e r i et al. (1998) also showed increased nuclear replication activity in Capsicum annum seed on priming with PEG.

In short priming of muskmelon seed with PEG showed increase germination, its speed, vigour in terms of root, shoot length and dry weight, root shoot ratio, lowered electrical conductance and higher dehydrogenases activity.

\section{REFERENCES}

Bradford, K.J., May, M., Hoyle, B.J., Skibinski, Z.S., Scolt, S.J. and Tyler K.B. 1988. Seed and soil treatments to improve emergence of muskmelon from cold or crusted soils. Crop Sci. 28:1001-1005.

Burton, K. 1955. Study of conditions and mechanism of diphenylamine reaction for colorimetric estimation of DNA. Biochem. J. 62:315-323.

Heydecker, W. 1977. Stress and seed germination p 240-282. In: A.A. Khan (ed). The Physiology and biochemistry of seed dormancy and germination. Elsevier/North Holland, Amsterdam.

Khan, A. A., KarLing T., Knypl, J.S., Borkowska, B. and Pouell, L.E. 1976. Osmotic conditioning of seeds. Physiological and Biochemical changes. Acta Hort. 83:267-68.

Lanteri, S., Quagliotti, L., Belletti, P., Scordino, A., Triglia, A., Musumeci, F. 1998. Delayed luminescence and priming - induced nuclear replication of unaged and controlled deteriorated pepper seeds (Capsicum annum L.). Seed Sci. \& Technol.: 26(2):413-424.

Louis, S. and Gifford, R.H. 1962. Changes in 3' nucleotidaze during the germination of wheat embryos. Arch. Biochem. Biophys. 96:534-554.

Maguire, J.D. 1962. Speed of germination and in selection and evaluation for seedling emergence and vigour. Crop. Sci. 2:176-177.

Mathews, S. and R. Whitebread 1968. Factors affecting pre-emergence mortality in peas. I. An association between seed exudates and the incidence of pre-emergence mortality in wrinkle seeded peas. Plant Path. 17:11-17. 
Mauromicale, G. and Cavallaro, V.1997. A comparative study of the effects of different compounds on priming of tomato seed germination under sub-optimal temperatures. Seed Sci. \& Technol. 25(3):399-408.

Mauromicale, G. and Cavallaro, V., Quagliotti, L.and Belletti, P. 1994. Effects of seed osmoconditioning on emergence characteristics of the summer squash (Cucurbita pepo L.). Acta Horticulturae. No.362:221-228.

Nerson, H. and Govers, A. 1986. Salt priming of muskmelon seed for low temperature germination. SciHortic. (Amsterdam). 28:85-91.

Rivas, M., Sundstrom F.J. and Edward R. 1984. Germination and crop development of hot pepper after seed priming. HortScience 19:279-281.

S a chs, M. 1977. Priming of watermelon seeds for low temperature germination. J. Amer. So.Hort.Sci.192:175-178.

Sen, S. and Osborne, D.J. 1964. Germination of rye embryos following hydration dehydration treatments: Enhancement of protein and RNA synthesis and earlier induction of DNA replication. J. Expl. Bot. 25:1010-1019.

Smille, R.H. and Krotkov, G. 1960. The estimation of nucleic acid in some algae and higher plants. Can. J. Bot. 38:31-49.

\section{Korzystny wpływ osmokondycjonowania na zachowanie się nasion melona (Cucumis melo)}

\section{Streszczenie}

Nasiona dwóch odmian melona (Cucumis melo) były osmokondycjonowane glikolem polietylenowym ( $\mathrm{PEG}$ ) i $\mathrm{KNO}_{3}$ dla poprawienia ich reakcji na niskie temperatury. Użycie obu wymienionych preparatów zwiększyło procent i szybkość kiełkowania, wigor roślin określany ich suchą masą i wielkością siewek oraz stosunek korzeń/pęd. $\mathrm{KNO}_{3}$ miał bardziej wyraźny wpływ na wszystkie wymienione cechy. Inne parametry wigoru, np. przewodnictwo elektryczne cieczy otrzymanej w wyniku przemywania nasion ulegało obniżeniu pod wpływem osmokondycjonowania, podczas gdy aktywność dehydrogenazy i amylaz była zwiększona. 
Vol., z. (1-2) - 1999

$127-137$

\title{
Wpływ regulatorów wzrostu na wzrost $\mathrm{i}$ kwitnienie Pelargonium x hortorum L.H. Bailey.
}

\section{ANNA POBUDKIEWICZ, JOANNA NOWAK}

\author{
Instytut Sadownictwa i Kwiaciarstwa, ul. Pomologiczna 18, 96-100 Skierniewice
}

A. Pobudkiewicz, J. Nowak (Research Institute of Pomology and Floriculture, Pomologiczna 18, 96-100 Skierniewice, Poland).

The effect of growth regulators on growth and flowering of Pelargonium x hortorum L.H. Bailey.

(Otrzymano: dn. 02.07.1999)

\section{S u m m a r y}

\begin{abstract}
Pelargonium $x$ hortorum L.H. Bailey cv. 'Ina' and 'Bargpalais' were grown in $10 \mathrm{~cm}$ pots. Growth retardants were applied as a spray, when plants were $5-10 \mathrm{~cm}$ high. Plants with a good habit were obtained using single application of flurprimidol at $15 \mathrm{mg} \mathrm{l}^{-1}$. Daminozide applied twice at concentrations of 3500 and 4500 was ineffective in growth retardation of geranium. Flurprimidol treatment at concentration of $15 \mathrm{mg} \mathrm{l}^{-1}$ had no significant influence on the flower longevity of plants sprayed with etephon at concentrations of 10,50 and $100 \mathrm{mg} \mathrm{l}-1$. Etephon was phytotoxic to geranium flowers depending on concentration and flower growth stage. The most sensitive to etephon application were fully open flowers and least sensitive were flower buds without visible petals.
\end{abstract}

Key words: growth regulators, growth, flowering, Pelargonium $x$ hortorum

\section{WSTĘP}

Pelargonia jest rośliną o uniwersalnym zastosowaniu. Służy do obsadzania kwietników, rabat, skrzynek balkonowych. Może być także wykorzystana jako roślina okrywowo-zadarniająca na terenowych skłonach oraz jako roślina doniczkowa do dekoracji mieszkań. Do uprawy doniczkowej wiele odmian nie nadaje się ze względu na zbyt długie pędy kwiatostanowe, a także mało zwarty pokrój. Skuteczną metodą skarlenia oraz poprawy pokroju roślin ozdobnych jest stosowanie retardantów wzrostu. $\mathrm{Z}$ dostępnej literatury wynika, że badań nad zastosowaniem flurprimidolu w uprawie pelargonii dotychczas nie prowadzono. Flurprimidol należy do grupy pirymidyn i jest 
retardantem nowej generacji. Działa skutecznie stosowany zarówno dolistnie (Pobudkiewicz i Nowak, 1992) jak i doglebowo (Pobudkiewicz i Nowak, 1994 b). Jest retardantem silnie działającym, o długim okresie aktywności w roślinach i co ważne nie jest fitotoksyczny. Badania prowadzone w Instytucie Sadownictwa i Kwiaciarstwa nad skarlaniem kwitnących roślin doniczkowych wykazały, że flurprimidol skutecznie skarla oraz poprawia pokrój m.in. Lilium (Pobudkiewicz i Nowak, 1992), Dianthus caryophyllus L. (Pobudkiewicz i Nowak, 1994 a), Tulipa (Pobudkiewicz i Nowak, 1994 b) Euphorbia pulcherrima Willd. (Pobudkiewicz i wsp., 1995) i Dendranthema grandiflora Tzvelev (Pobudkiewicz i Nowak, 1997).

Jednym z problemów w uprawie pelargonii jest przedwczesne opadanie płatków kwiatowych. Zjawisko to jest często obserwowane podczas transportu lub przechowywania roślin przed sprzedażą. W procesie opadania płatków dużą rolę odgrywa etylen $\left(\mathrm{C}_{2} \mathrm{H}_{4}\right)$, który w niewielkich ilościach jest niezbędny dla wzrostu i rozwoju roślin, natomiast gdy dochodzi do akumulacji dużych ilości tego gazu w atmosferze otaczającej rośliny może być toksyczny (Yang, 1985). Duże ilości etylenu produkują rośliny pod wpływem czynników stresowych (Yang, 1985). Źródłem etylenu mogą być dojrzewające owoce (Sherman, 1985; Dunlap i wsp., 1990), a także spaliny i dym (Blanpied, 1985). Produkcja etylenu przez rośliny może być zahamowana przez inhibitory biosyntezy etylenu. Nieliczne dane literaturowe wskazują, że retardanty wzrostu mogą również hamować ten proces wpływając na przemianę ACC w etylen (Sauerbrey i wsp., 1987; Grossmann i wsp., 1989).

Celem niniejszej pracy było:

a) skarlenie oraz poprawa pokroju i zwartości pelargonii przy użyciu flurprimidolu

b) określenie wpływu flurprimidolu na wrażliwość kwiatów pelargonii na etylen,

c) ocena wrażliwości kwiatów pelargonii na etylen.

\section{MATERIAŁ I METODY}

Ukorzenione sadzonki Pelargonium x hortorum L.H. Bailey 'Ina' i 'Bargpalais' posadzono do doniczek o średnicy $10 \mathrm{~cm}$. Podłoże o pH - 6,2 stanowiła mieszanina torfu wysokiego i piasku w stosunku 4:1. Rośliny nawożono nawozami wieloskładnikowymi (Novokont lub Hydrovit) 1 raz w tygodniu, a zabiegi ochrony wykonywano interwencyjnie.

\section{a) Doświadczenie z retardantami wzrostu}

W doświadczeniu stosowano flurprimidol (Topflor $015 \mathrm{SL}$ ) zarejestrowany na polskim rynku do stosowania w uprawie niektórych roślin doniczkowych, a jako retardantu porównawczego użyto daminozydu (B-Nine $85 \mathrm{SP}$ ) drugiego retardantu zarejestrowanego do stosowania w uprawie roślin ozdobnych. Retardanty wzrostu stosowano dolistnie. Flurprimidol podano jednokrotnie w stężeniach: 7,5 i $15 \mathrm{mg} \mathrm{l}^{-1}$, a daminozyd dwukrotnie w stężeniach 3500 i $4500 \mathrm{mg} \mathrm{l}^{-1}$. Rośliny kontrolne opryskiwano wodą w tym samym czasie. Po raz pierwszy retardanty zastosowano na rośliny rozkrzewiające się, gdy miały one 5-10 cm wysokości, a daminozyd po raz drugi użyto po dwóch tygodniach. 
Doświadczenie założono w układzie bloków losowych z 6 powtórzeniami i 6 roślinami w powtórzeniu. Wyniki pomiarów opracowano statystycznie metodą analizy wariancji w układzie jednoczynnikowym. Istotność różnic pomiędzy średnimi oceniano testem t-Duncana przy poziomie 5\%. Doświadczenie prowadzono w okresie wiosennym, w ciągu 2 lat. Pomiary wysokości i średnicy roślin oraz średnicy kwiatostanów wykonano, gdy trzy kwiatostany na roślinie były w pełni rozwinięte. Liczbę dni do kwitnienia liczono od momentu sadzenia roślin do doniczek. Wyniki przedstawione na rysunkach są to średnie z dwu serii doświadczenia.

\section{b) Doświadczenie z etefonem}

Połowę doświadczenia stanowiły rośliny nie traktowane retardantem, a drugą część rośliny opryskiwane jednokrotnie flurprimidolem w stężeniu $15 \mathrm{mg} \mathrm{l}^{-1}$, gdy miały one $5-10 \mathrm{~cm}$ wysokości. Na początku kwitnienia obie grupy pelargonii opryskiwano jednokrotnie roztworem etefonu [(Ethephon-A) - B.V. Luxan Elst (GLD)] w stężeniach: $0,10,50 \mathrm{i} 100 \mathrm{mg} \mathrm{l}^{-1}$. W dniu stosowania etefonu na roslinach były kwiaty w pełni rozwinięte, pąki kwiatowe $\mathrm{z}$ widocznymi płatkami oraz pąki kwiatowe bez widocznych płatków. Etykietą oznaczono po 10 kwiatów na roślinie $z$ każdej w/w faz rozwojowych. W doświadczeniu notowano trwałość kwiatów na roślinach, a także prowadzono obserwacje uszkodzenia kwiatów i liści powodowanych przez etefon. Kontrolę stanowiły rośliny nie opryskiwane etefonem.

Doświadczenie prowadzono w układzie bloków losowych z 2 powtórzeniami i 4 roślinami w powtórzeniu. Wyniki pomiarów opracowano statystycznie metodą analizy wariancji, a do oceny istotnośći różnic pomiędzy średnimi użyto testu t-Duncana przy poziomie $5 \%$.

\section{WYNIKI I DYSKUSJA}

Daminozyd nie wpływał na wysokość pelargonii 'Ina' i 'Bargpalais' (dane nie prezentowane). Na początku kwitnienia stwierdzono natomiast istotne różnice pomiędzy wysokością roślin kontrolnych, a wysokością roślin traktowanych flurprimidolem w stężeniach: 7,5 i $15 \mathrm{mg} \mathrm{l}^{-1}$ (rys. 1A i 2A). Najniższe rośliny, o wysokości $18-19 \mathrm{~cm}$, uzyskano stosując flurprimidol w stężeniu $15 \mathrm{mg} \mathrm{l}^{-1}$. Badania nad skarlaniem innych roślin wykazały, że przy użyciu takiego stężenia poprawiono pokrój Dendranthema grandiflora Tzvelev (Pobudkiewicz i Nowak, 1997), ale znacznie większych dawek flurprimidolu użyto do skarlenia Lilium (Pobudkiewicz i Nowak, 1992) i Tulipa (Pobudkiewicz i Nowak, 1994), znacznie mniejszych dawek natomiast potrzeba było do skarlenia Nemathanthus gregarius (Pobudkiewicz, 1992 niepublikowane).

Pelargonie opryskiwane flurprimidolem były bardziej zwarte niż rośliny kontroIne. Średnica roślin pelargonii 'Ina' (rys. 1B) i 'Bargpalais' (rys. 2B) traktowanych flurprimidolem była istotnie mniejsza niż roślin nie opryskiwanych. Wpływ innych retardantów na średnicę roślin obserwowano także w doświadczeniach nad Pelargonium $x$ hortorum 'Ringo Rose' i 'Ringo White' (Latimer i Baden, 1994) oraz 'Medalion Dark Red', 'Aurora' i 'Pink Satisfaction' (Whipker i wsp., 1997). Flurprimidol wpływał w niewielkim stopniu również na średnicę kwiatostanu pelargonii 'Ina' (rys. 1C) i 'Bargpalais' (rys. 2C). Badania nad pelargoniami 'Multibloom Scarlet' i 'Red Elite', z użyciem 
unikonazolu (Starman i wsp., 1994) oraz 'Springtime', z użyciem paklobutrazolu (And rasek, 1989) również wykazały, że rośliny traktowane retardantem miały mniejszą średnicę kwiatostanu niż rośliny kontrolne.

Flurprimidol nie wpływał istotnie na liczbę dni do kwitnienia zarówno odmiany Ina (rys. 1D) jak i Bargpalais (rys. 2D). Podobne spostrzeżenia poczyniono w doświadczeniach z pelargonią 'Smash Hit' (Cox i Keever, 1988) oraz 'Yours Truly' (Tay a ma i Carver, 1990). Wpływ retardantów na liczbę dni do kwitnienia roślin podkreślano jednak w niektórych pracach badawczych. Norremark i Andersen (1994), Andrasek (1989) i Cox (1991) donoszą, że paklobutrazol zmniejszał liczbę dni do kwitnienia pelargonii. Latimer i B aden (1994) zaobserwowali, że paklobutrazol, ancymidol i CCC w jednym roku badań przyśpieszały kwitnienie pelargonii, natomiast stosowane w następnym roku nie wpływały istotnie na termin kwitnienia roślin. Badania Starmana i wsp. (1994) nad skarlaniem pelargonii 'Red Elite' wykazały natomiast, że unikonazol stosowany dolistnie opóźniał kwitnienie roślin o 3 dni, a podany doglebowo przyśpieszał kwitnienie o 4 dni, w porównaniu do roślin kontrolnych.

Liście oraz kwiaty pelargonii 'Ina' i 'Bargpalais' traktowanych retardantem miały intensywniejszy kolor niż liście i kwiaty roślin kontrolnych. Nie obserwowano objawów fitotoksyczności flurprimidolu.

$\mathrm{W}$ porównaniu do roślin kontrolnych, flurprimidol w stężeniu $15 \mathrm{mg} \mathrm{l}^{-1}$ nie wpływał istotnie na trwałość kwiatów, które w dniu opryskiwania etefonem w stężeniach: 10,50 i $100 \mathrm{mg} \mathrm{l}^{-1}$ były w pełni rozwinięte, $\mathrm{w}$ fazie pąka $\mathrm{z}$ widocznymi płatkami lub w fazie pąka bez widocznych płatków (rys. 3 i 4).

Istotny wpływ na trwałość kwiatów pelargonii miała dawka etefonu, a także faza rozwoju kwiatów, w której był on stosowany. Badania prowadzone na innych gatunkach roślin również wskazują, że reakcja roślin na etylen w dużym stopniu zależy od jego dawki. Badania Serek (1993) wykazały, że etefon w stężeniu $50 \mathrm{mg} \mathrm{l}^{-1}$ nie był toksyczny dla roślin, ale w stężeniu $500 \mathrm{mg} \mathrm{l}^{-1}$ istotnie skracał trwałość kwiatów na roślinach Rosa hybrida 'Victory Parade'. Etefon w stężeniu $5 \mathrm{mg} \mathrm{l}^{l^{-1}}$ nie wpływał istotnie na jakość kwiatów Lathyrus odoratus L., ale w stężeniu $100 \mathrm{mg} \mathrm{l}^{-1}$ był on toksyczny dla roślin (Ohkawa i wsp., 1991).

W badaniach własnych najbardziej wrażliwe na działanie etefonu były kwiaty w pełni rozwinięte. Trwałość kwiatów roślin traktowanych etefonem w stężeniach 50 i $100 \mathrm{mg} \mathrm{l}^{-1}$ była krótsza niż 2 dni (rys. 3A i 4A). Etefon tylko w najmniejszym $\mathrm{z}$ badanych stężeń tj. $10 \mathrm{mg} \mathrm{l}^{-1} \mathrm{w}$ niewielkim stopniu wpływał na trwałość kwiatów w porównaniu do roślin nie traktowanych tym związkiem. Dużą wrażliwość na etylen kwiatów w pełni rozwiniętych wykazały także badania prowadzone na innych gatunkach roślin doniczkowych np. Impatiens X hawkeri 'Sunfire' (Dostal i wsp., 1991), Streptocarpus $x$ hybridus (Rewinkel-Jansen, 1986), Schlumbergera truncata L. (Cameron i Reid, 1981) i Kalanchoe blossfeldiana Poelln 'Cherie' (Marousky i Harbough, 1979).

Stosunkowo mało wrażliwe na działanie etefonu były pąki kwiatowe $\mathrm{z}$ widocznymi płatkami. Etefon w stężeniu $10 \mathrm{mg} \mathrm{l}^{-1}$ nie miał istotnego wpływu na trwałość kwiatów pelargonii 'Ina' i 'Bargpalais', ale w stężeniach: 50 i $100 \mathrm{mg} \mathrm{l}^{-1}$ skracał ją o kilka dni (rys. 3B i 4B). Najmniejszą trwałość miały kwiaty roślin opryskiwanych etefonem w stężeniu $100 \mathrm{mg} \mathrm{l}^{-1}$, trwałość kwiatów odmiany Ina wynosiła ok. 2,5 dnia (rys. 4B) i odmiany Bargpalais (rys 3B) ok. 3 dni. 
Rys. 1. Wpływ flurprimidolu na wysokość (A), średnicę rośliny (B), średnicę kwiatostanu (C) oraz liczbę dni kwitnienia (D) pelargonii 'Ina'.

Fig. 1. Effect of flurprimidol on the height (A), canopy diameter (B), inflorescence diameter (C) and numbers of days to flowering (D) of geranium 'Ina'.
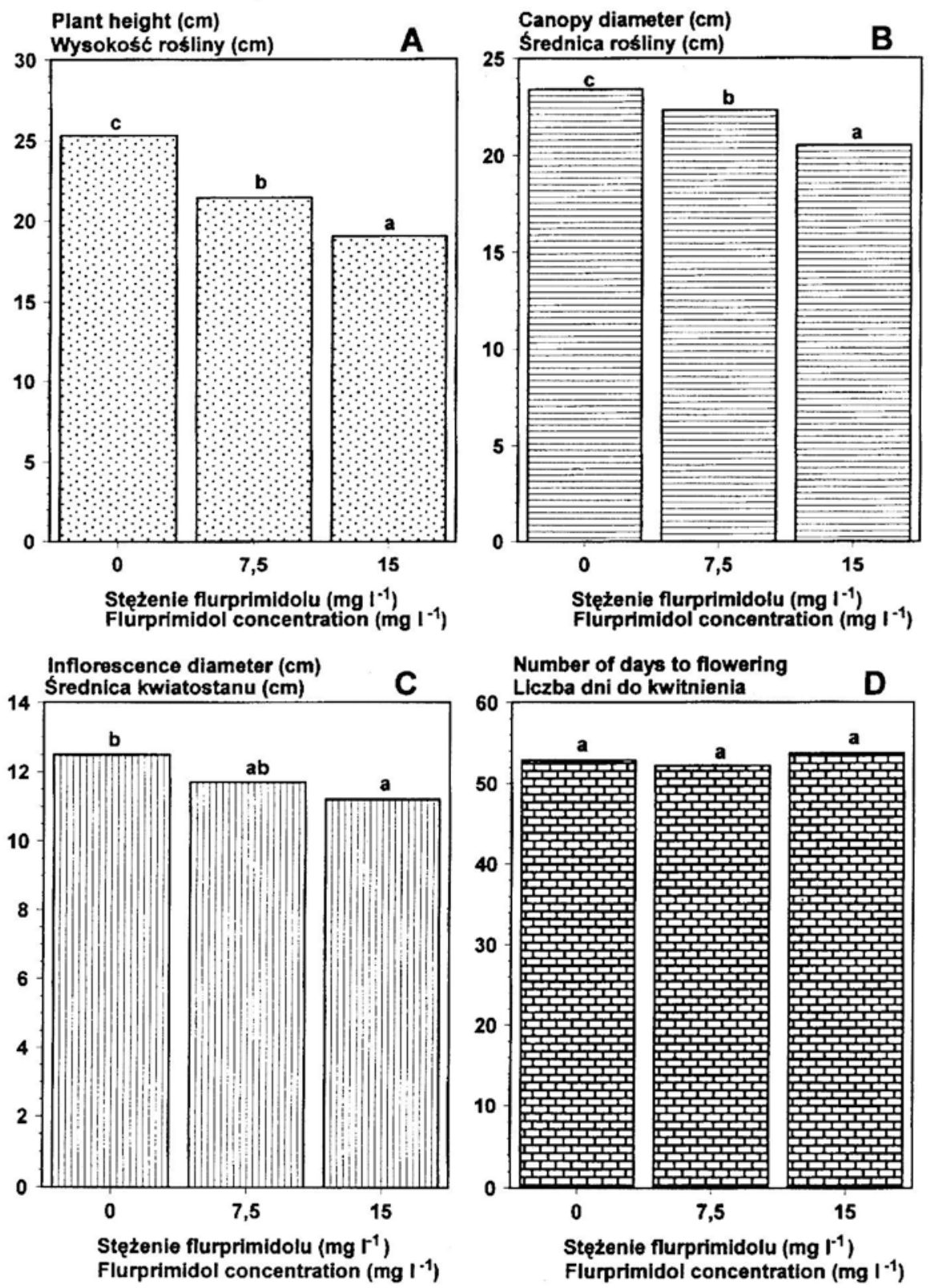

Średnie oznaczone tą samą literą nie różnią się istotnie przy poziomie istotności $5 \%$.

Means followed by the same letter do not differ significantly at $5 \%$. 
Rys. 2. Wpływ flurprimidolu na wysokość (A), średnicę rośliny (B), średnicę kwiatostanu (C) oraz liczbę dni kwitnienia (D) pelargonii 'Bargpalais'.

Fig. 2. Effect of flurprimidol on the height (A), canopy diameter (B), inflorescence diameter (C) and numbers of days to flowering (D) of geranium 'Bargpalais'.
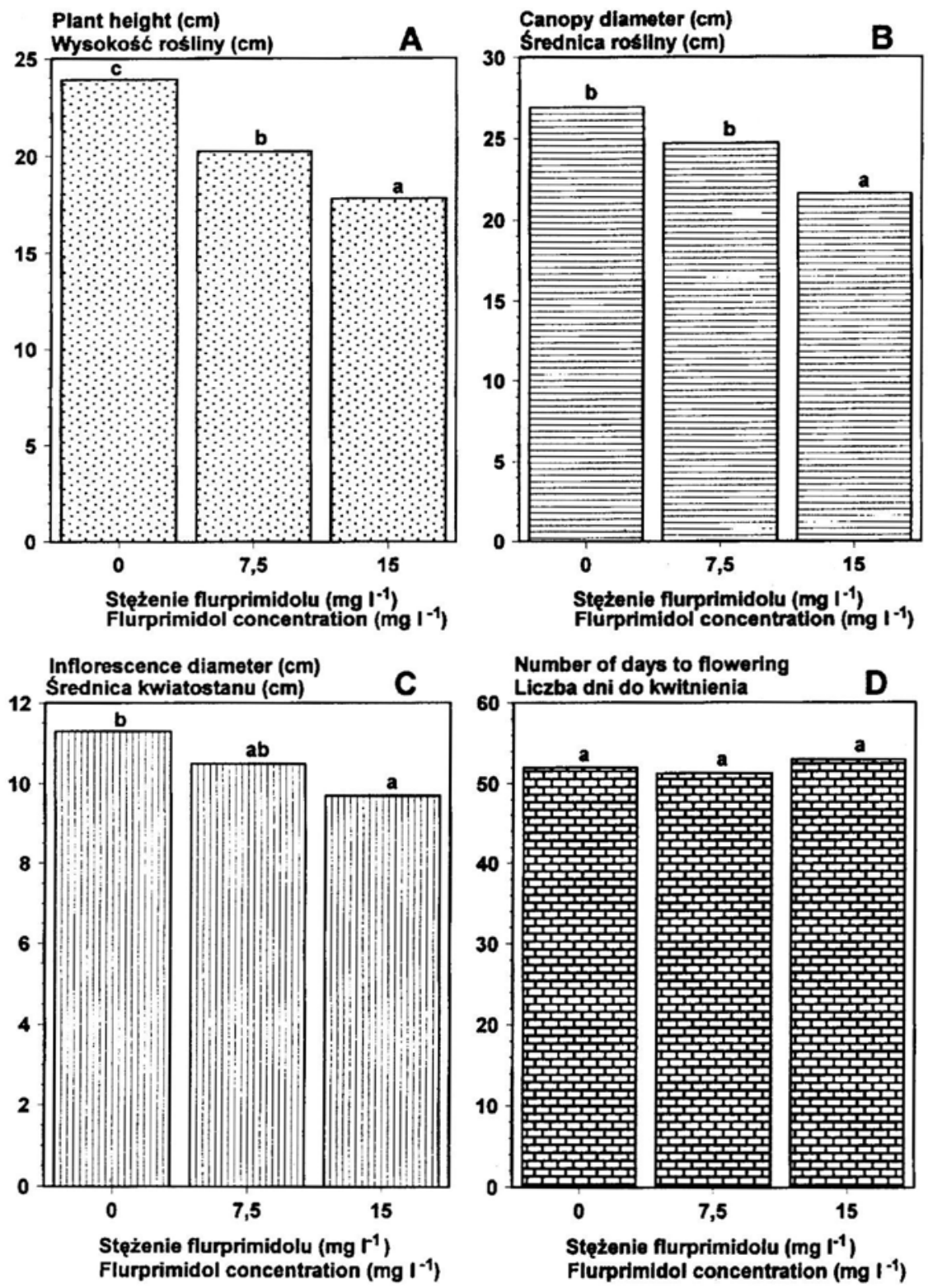

Średnie oznaczone tą samą literą nie różnią się istotnie przy poziomie istotności $5 \%$.

Means followed by the same letter do not differ significantly at $5 \%$. 
Rys. 3. Wpływ flurprimidolu na trwałość kwiatów pelargonii, które w dniu opryskiwania etefonem były: w pełni rozwinięte (A), w fazie pąka z widocznymi płatkami (B) lub w fazie pąka bez widocznych płatków (C).

Fig. 3. Effect of flurprimidol on longevity of geranium flowers, which on the day of etephon treatment were: fully open (A), at the bud stage with visible petals (B) or at the bud stage without visible petals.
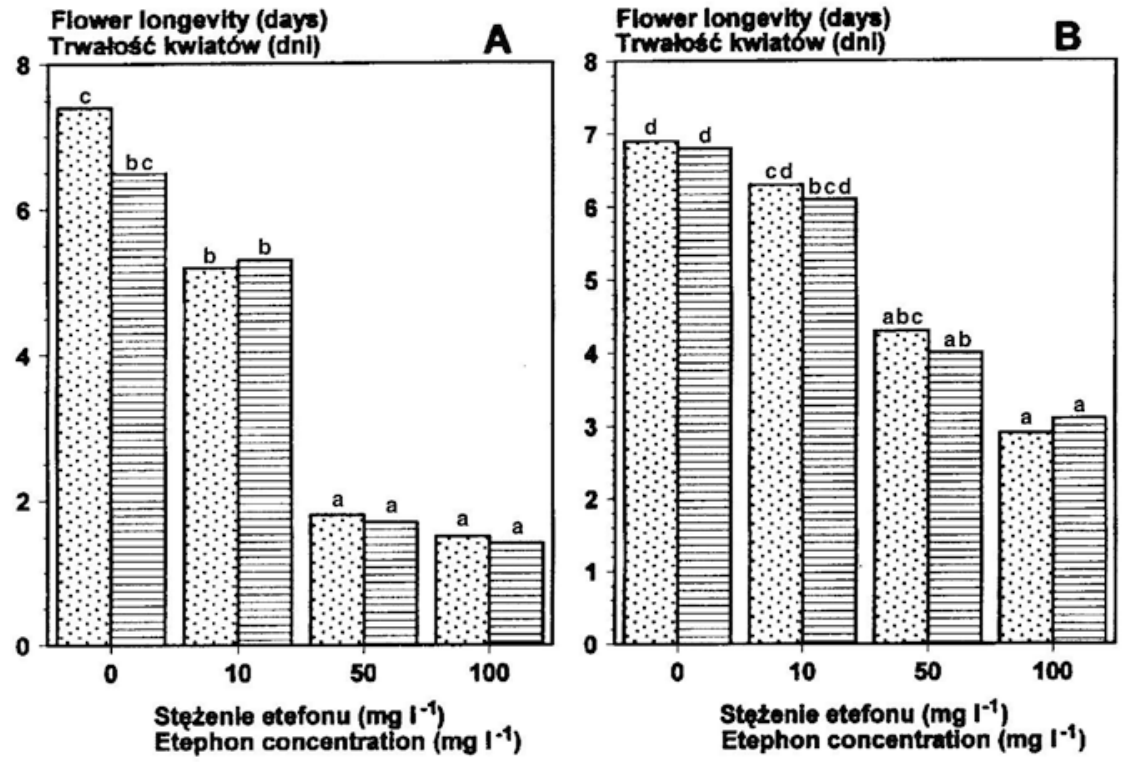

'Bargpalais'

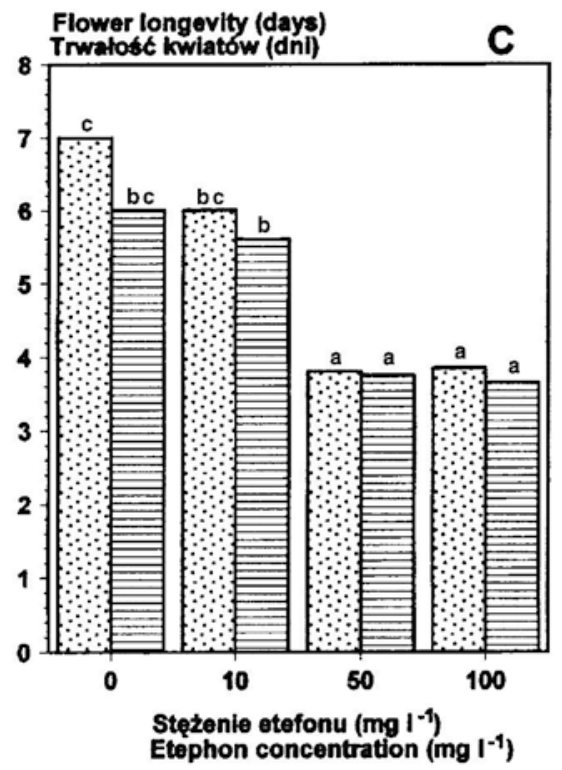

Średnie oznaczone tą samą literą nie różnią się istotnie przy poziomie istotności 5\%.

Means followed by the same letter do not differ significantly at $5 \%$ level. 
Rys. 4. Wpływ flurprimidolu na trwałość kwiatów pelargonii, które w dniu opryskiwania etefonem były: w pełni rozwinięte (A), w fazie pąka $z$ widocznymi platkami (B) lub w fazie pąka bez widocznych platków (C).

Fig. 4. Effect of flurprimidol on longevity of geranium flowers, which on the day of etephon treatment were: fully open (A), at the bud stage with visible petals (B) or at the bud stage without visible petals.
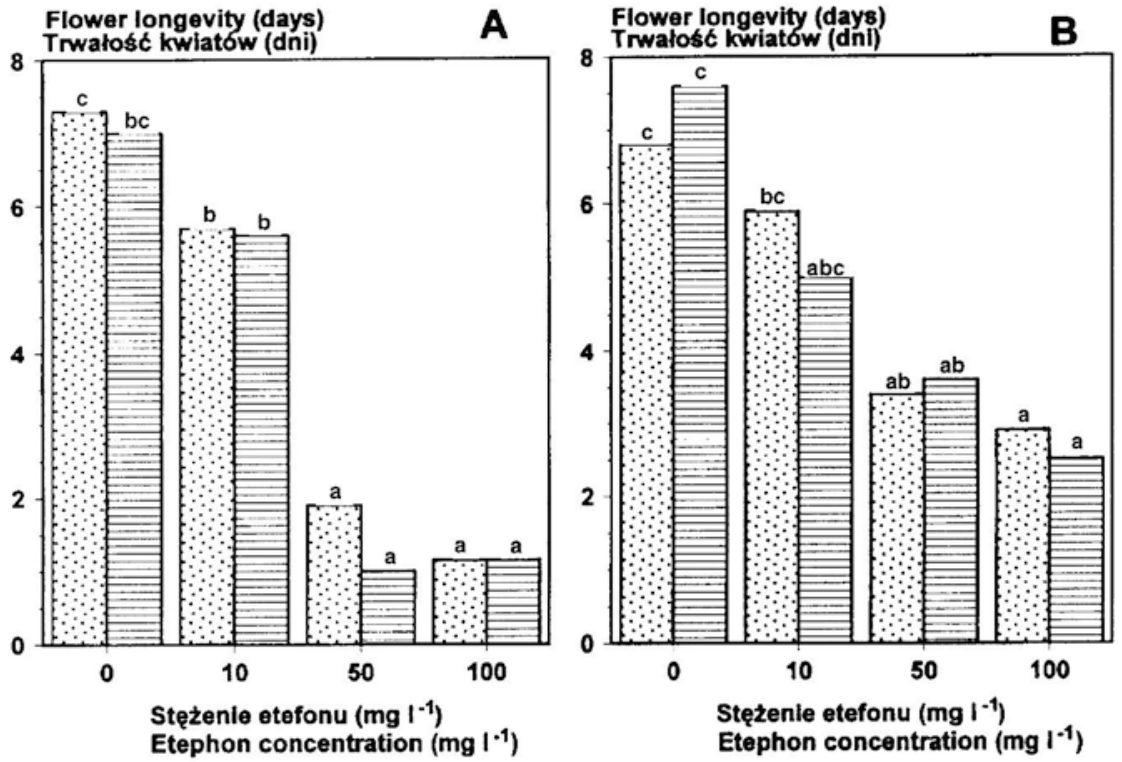

\section{'Ina'}

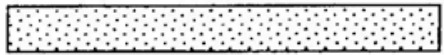

Rośliny nie traktowane flurprimidolem Plants not treated with flurprimidol

Rośliny traktowane flurprimidolem w stężeniu $15 \mathrm{mg} \mathrm{l}^{-1}$

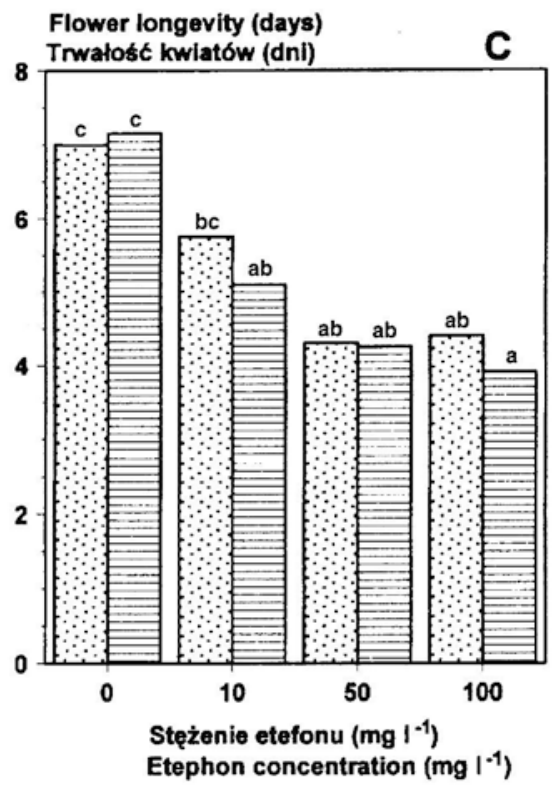

Średnie oznaczone tą samą literą nie różnią się istotnie przy poziomie istotności $5 \%$.

Means followed by the same letter do not differ significantly at $5 \%$ level. 
Najmniej wrażliwe na działanie etefonu były pąki kwiatowe bez widocznych płatków. W porównaniu do roślin kontrolnych, etefon w stężeniach: 50 i $100 \mathrm{mg} \mathrm{l}^{-1}$ wpływał w istotny sposób na trwałość kwiatów badanych odmian pelargonii, skracając ją o ok. 3 dni (rys. 3C i 4C).

Uszkodzeniom ulegała ta część płatka pelargonii, która była widoczna w czasie zabiegu, dlatego też najbardziej uszkodzone były kwiaty, które w dniu opryskiwania roślin etefonem były w pełni rozwinięte. Objawy toksyczności na płatkach kwiatowych były widoczne już następnego dnia po opryskiwaniu roślin etefonem w stężeniach wyższych niż $10 \mathrm{mg} \mathrm{l}^{-1}$. W czasie kwitnienia niewielkie uszkodzenia występowały także na kwiatach tych roślin, które w dniu stosowania etefonu w stężeniach: 50 i $100 \mathrm{mg} \mathrm{l}^{-1}$ były $\mathrm{w}$ fazie pąka $\mathrm{z}$ widocznymi płatkami. Zmiany te w nieznacznym stopniu wpływały na wartość dekoracyjną kwiatów, gdyż występowały tylko na dolnej stronie płatka, praktycznie były więc niezauważalne. Objawów toksyczności etefonu nie obserwowano na kwiatach, które w dniu zabiegu były w fazie pąka bez widocznych płatków.

Liście oraz pędy pelargonii pozostały niewrażliwe na opryskiwanie etefonem niezależnie od stężenia. Podobne badania na kwitnących roślinach doniczkowych wykazały, że liście niektórych gatunków roślin są dość odporne na działanie etylenu. Pod wpływem egzogennego etylenu nie stwierdzono objawów fitotoksyczności na liściach Begonia elatior 'Sirene', zaobserwowano natomiast opadanie pąków kwiatowych i kwiatów (Hoyer, 1985). Obserwacje te są również zgodne z badaniami Barden i Hanana (1972), którzy nie stwierdzili zmian na liściach i łodygach goździka Dianthus caryophyllus L. 'White Sim' przetrzymywanych w atmosferze o zwiększonej zawartości etylenu.

\section{WNIOSKI}

1. Flurprimidol w stężeniu $15 \mathrm{mg} \mathrm{l}^{-1}$ stosowany dolistnie, gdy rośliny mają 5-10 cm wysokości, skarla pelargonię i poprawia jej pokrój.

2. Daminozyd nie skarla pelargonii 'Ina' i 'Bargpalais'.

3. Kwiaty całkowicie rozwinięte pelargonii 'Ina' i 'Barpalais' są najbardziej wrażliwe na etylen, dlatego rośliny powinno się transportować we wcześniejszej fazie rozwoju, tj., gdy kwiaty są w fazie pąka.

4. Flurprimidol nie wpływa na wrażliwość kwiatów pelargonii na etylen.

\section{LITERATURA}

A ndrase k K. 1989. Increasing the ornamental value of Hibiscus rosa-sinensis and Pelargonium $x$ hortorum cv. Springtime by using gibberellin inhibitor growth regulator. Acta Hortic. 251: 329-333.

B arden L.E., J.J. Han a n, 1972. Effect of ethylene on carnation keeping life. J. Amer. Soc. Hort. Sci., 97 (6): 785-788.

B lanpied G.D., 1985. Introduction to the Symposium. HortScience, 20 (1): 40-41.

Cameron A.C., M.S. Reid., 1981. The use of silver thiosulfate anionic complex as a foliar spray to prevent flower abscission of zygocactus. HortScience, 16 (6): 761-762.

Cox D.A., 1991. Gibberellic acid reverses effects of excess paclobutrazol on geranium. HortScience. 26 (1): 39-4

Cox D.A., Keever G.J., 1988. Paclobutrazol as a growth retardant for geranium and zinnia. Research Report Series Alabama Agric. Exper. Station. 5: 18-19. 
Dunlap J.R., S.E. Lingle, G.E. Lester, 1990. Ethylene production in netted muskmelon subjected to postharvest heating and refrigerated storage. HortScience, 25 (2): 207-209.

Dostal D.L., O.N. Agniew, J.R. Gladon, L.J. Weigle, 1991. Ethylene, simulated shipping, STS, and AOA affect corolla abscission of new Guinea impatiens. HortScience, 26 (1): 47-49.

Grossmann K., C. Hauser, E. Sauerbrey, H. Fritsch, O. Schmidt, J. J ung, 1989. Plant growth retardants as inhibitors of ethylene production. J. Plant Physiol., 134: 538-543.

Hoye r L.,1985. Bud and flower drop in Begonia elatior 'Sirene' caused by ethylene and darkness. Acta Hortic., 167: 287-294.

Latimer J.G., B aden S.A., 1994. Persistent effects of plant growth regulators on landscape performance of seed geraniums. J. Envir. Hortic. 12 (2): 150-154.

Marousky F.J., B.K. Harbaugh, 1979. Ethylene-induced floret sleepiness in Kalanchoe blossfeldiana Poelln. HortScience, 14 (4): 505-507.

Norremark I., A. Andersen, 1990. Effect of paclobutrazol on seed propagated Pelargonium $x$ hortorum L.H. Bailey. Gartenbawissenschaft, 55 (1): 1-8.

Ohkawa K., Y. Ishihara, H. Hyodo, A. Kano, 1991. Bud drop of sweet pea (Lathyrus odoratus L.) as affected by ethylene. J. Japan. Soc. Hort. Sci., 60 (2): 405-408.

Pobudkiewicz A., J. Nowak, 1992. Effect of flurprimidol and silver thiosulfate (STS) on the growth and flowering of 'Prima' lilies grown as pot plants. Acta Hortic., 325: 193-198.

Pobudkiewicz A., J. Nowak, 1994 a. The influence of flurprimidol and uniconazole on growth of the CMM dwarf Dianthus caryophyllus L. cv. Snowmass. J.Fruit Ornam. Plant Res. Vol II (4): 135-142.

Pobudkiewicz A., J. Nowak, 1994 b. Wpływ retardantów wzrostu na wzrost i kwitnienie polskich odmian tulipanów uprawianych w doniczkach. Ogólnopolska konferencja „Tulipany wczoraj, dziś i jutro". Skierniewice.

Pobudkiewicz A., J.S. Nowak, J. Nowak, 1995. Stosowanie nowego retardantu wzrostu - flurimidol (Topflor) w uprawie Euphorbia pulcherrima Willd. 'Lilo'. Materiały Ogólnop. Konf. Naukowej „Materiały Praktyce Ogrodniczej”. Lublin, (II): 879-882.

Pobudkiewicz, A., J. Nowak, 1997. Response of chrysanthemum (Dendranthema grandiflora Tzvelev) cvs Altis and Surf to flurprimidol application. J. Fruit Ornam. Plant Res. 5 (1): 43-52.

Reid M.S., 1985. Ethylene and abscission. HortScience, 20 (1): 45-50.

Rewinkel-Jansen M.J.H., 1986. Flower and bud abscission of streptocarpus and the use of ethylene sensitiveness inhibitors. Acta Hortic., 181: 419-423.

Sauerbrey E., K. Grossmann, J. Jung, 1987. Influence of growth retardants on the internode elongation and ethylene production of sunflower plants. Physiol. Plant., 70: 8-12.

Serek M., 1993. Ethephon and silver thiosulfate affect postharvest characteristics of Rosa hybrida 'Victory Parade'. HortScience, 28 (3): 199-200.

Sherman M., 1985. Control of ethylene in the postharvest environment. HortScience, 20: 57-60.

Starman T.W., Cerny T. A., Grindstaff T.L., 1994. Seed geranium growth and flowering responses to uniconazole. HortScience. 29 (8): 865-867.

Tay a ma H.K., Carver S.A., 1990. zonal geranium growth and flowering responses to six growth regulators. HortScience. 25 (1): 82-83.

Whipker B.E., Hammer P.A., Connell J., 1997. Vegetatively propagated geranium response to single and multiple applications of chemical growth retardants. PGRSA-Quarterly. 25 (3): 130-133.

Yang S.F., 1985. Biosynthesis and action of ethylene. HortScience, 20 (1): 45.

\section{Streszczenie}

Pelargonium $x$ hortorum L.H. Bailey 'Ina' i 'Bargpalais' uprawiano w doniczkach o średnicy $10 \mathrm{~cm}$. Retardanty wzrostu stosowano dolistnie, gdy rośliny miały $5-10 \mathrm{~cm}$ wysokości. Rośliny o dobrym pokroju otrzymano stosując flurprimidol jednokrotnie, w stężeniu $15 \mathrm{mg} \mathrm{l}^{-1}$. Daminozyd podany dwukrotnie w stężeniach $3500 \mathrm{i}^{4} 500 \mathrm{mg} \mathrm{l}^{-1}$ okazał się nie skuteczny w skarlaniu pelargonii. Flurprimidol w stężeniu $15 \mathrm{mg} \mathrm{l}^{-1}$ nie 
wpływał istotnie na trwałość kwiatów roślin opryskiwanych etefonem w stężeniach: 10, $50 \mathrm{i} 100 \mathrm{mg} \mathrm{l}^{-1}$. Etefon był toksyczny dla kwiatów pelargonii w zależności od stężenia oraz fazy rozwoju kwiatu. Najbardziej wrażliwe na działanie etefonu były kwiaty w pełni rozwinięte, a najmniej wrażliwe okazały się pąki kwiatowe bez widocznych płatków. 